\title{
The occurrence of floods and the role of climate variations from 1880 in Calabria (Southern Italy)
}

\author{
M. Polemio ${ }^{1}$ and O. Petrucci ${ }^{2}$ \\ ${ }^{1}$ National Research Council - Research Institute for Geo-Hydrological Protection (CNR-IRPI), Bari, Italy \\ ${ }^{2}$ National Research Council - Research Institute for Geo-Hydrological Protection (CNR-IRPI), Cosenza, Italy \\ Correspondence to: M. Polemio (m.polemio@ba.irpi.cnr.it)
}

Received: 13 December 2010 - Revised: 15 November 2011 - Accepted: 5 December 2011 - Published: 13 January 2012

\begin{abstract}
In this paper, we present a methodological approach based on a comparative analysis of floods that occurred in a wide region over a long period and the climatic data characterising the same period, focusing on the climate trend. The method simplifies the comparative analysis of several time series by defining some indexes (e.g. the monthly, bi-monthly, and ... $m$-monthly indexes of precipitation, temperature, wet days and precipitation intensity and the monthly flood number) that can be used to study phenomena such as floods that are characterised by spatial and temporal variability. The analysis was used to investigate the potential effect of climate variation on the damaging floods trend.

The approach was tested for the Calabria region (Italy) using historical flood and climatic data from 1880 to 2007. The results showed that the number of floods was correlated with the monthly indexes of precipitation, wet days, and daily precipitation intensity. The following trends were recognised: decreasing precipitation and wet days, almost constant precipitation intensity, increasing temperature, and linearly increasing floods. A second-order polynomial trend analysis showed a slight decrease in floods since the seventies, which might be explained by the favourable climatic conditions during the period and/or the effect of increasing awareness of flood vulnerability.
\end{abstract}

\section{Introduction}

The relationship between extreme meteorological events and climate changes is a challenging issue for scientists, especially considering the damaging effects that these extreme events can produce. Climate change is often viewed as the cause of the increases in both the frequency and magnitude of damaging effects resulting from such events (EEA, 2008).
Other studies have concluded that societal change and economic development were the principal factors responsible for the increasing losses from natural disasters to date (Pielke et al., 2008; Barredo, 2009, 2010). Finally, a third point of view is that a combination of climate change and societal factors has led to an increase in total damage, in particular damage caused by floods, and the increase in damage is associated with increased precipitation, population and wealth (Pielke and Downton, 2000).

Since the beginning of the 20th century, precipitation has been increasing by about $1 \%$ per decade over most midand high-latitude regions of the continental Northern Hemisphere. Still, in the second half of the century, there was a 2 $4 \%$ increase in the frequency of heavy precipitation (IPCC, 2001). In Europe, the percentage of winter rainfall appears to have increased mainly due to the increasing frequency of extremely wet seasons. These effects decrease from northern Europe to the Mediterranean basin. In particular, the Italian climate is becoming warmer and drier due to a reduction in both annual precipitation and wet days (Brunetti et al., 2004, 2006).

In the context of climate change, it is important to analyse both the frequency and the characteristics of Damaging Hydrogeological Events (DHEs), which are defined as episodes of severe weather conditions with heavy rainfall and strong winds (Petrucci et al., 2009, 2010a). During these events, a series of damaging phenomena such as landslides, floods, sea storms, and strong winds can cause human injuries, deaths, and economic damage in almost all economic frameworks and in a wide variety of climatic environments.

The present study is part of wider research that aims to analyse, in the context of climate change, the historical series of DHEs (Petrucci et al., 2009) or particularly damaging phenomena that occur during DHEs such as landslides (Polemio and Petrucci, 2010). We have focused on floods, particularly on flood disasters that are the result of the 
interaction between abnormally high water levels of a river or torrent and societal systems, as defined by Barredo (2009).

In populated areas, floods can kill or injure people (Antoine et al., 2001; Jonkman and Kelman, 2005; Ruin et al., 2008; Llasat, 2009; Polemio, 2010), cause severe economic losses (Merz et al., 2010), and damage road networks (Vinet, 2008) and residential buildings (Elmer et al., 2010). Floods are a difficult problem in regions where, because of either widespread economic activity or scarcity of flat areas, human settlements have developed on river plains with subsequent expansion dangerously close to flood-prone areas. Along the river banks the areas of flood expansion become progressively narrower while the amount of people and goods exposed to floods increases. In these situations, flood disasters are more likely to occur (Petrucci and Polemio, 2007; Barredo, 2009; Lara et al., 2010), and the damage trend over time depends on both climate change and urban development. Environmental degradation can be a secondary effect of economic development because expansion of human settlement without planning and sustainable resource management can increase vulnerability to floods and exacerbate their impact (Gupta et al., 2003). In addition, some human modifications might actually increase the long-run vulnerability; levees, for example, are intended to prevent damage from a flood of a stated magnitude, but when they overflow, the severity of flood disasters actually increases (White et al., 2001).

Depending on the data and methods used, four main approaches can be applied to investigate the relationship between floods and climate: the palaeo-approach, the quantitative approach, the historical approach, and the time series approach. Numerous studies have been conducted using either one or a combination of these approaches, as in this paper (previous experiences are cited describing each approach).

The palaeo-approach analyses palaeo-floods in relation to past climatic conditions. This approach considers the observation of peak discharge frequency and levels and focuses on natural and anthropogenic modifications, thus assessing the actual role of climate change (Benito et al., 2003; Ortega and Garzón, 2009).

The quantitative approach is based on mathematical or numerical one-dimensional to three-dimensional techniques for flow simulation in natural rivers and channels, based on different types of topographical, geomorphological, and hydraulic data (Cunge et al., 1980; Herget and Meurs, 2010; Ortega and Garzón, 2009; Polemio, 2010). The basic purpose is to quantify the peak water height, the discharge yield and/or the submerged area during a selected flood. Depending on the results, the so-called stage-damage curves can be set and used to estimate the damage according to the inundation depth (EMA, 2002).

The historical approach is based on flood data obtained from different information sources such as newspapers, historical documents, maps, epigraphic markers on historic buildings, etchings, paintings, scientific articles, books, and documentation available in the archives of public agencies. This approach has two main purposes: (a) to obtain data concerning rivers or torrents that lack instrumental data; and (b) to expand the observation period of instrumented rivers to the pre-measurement epoch, to improve the assessment of flood recurrence and trend (Benito et al., 2003; Herget and Meurs, 2010; Petrucci and Polemio, 2009; Polemio, 2010; Schmocker-Fackel and Naef, 2010). In cases where the river flow is extremely variable, discontinuous or sporadic, as widely observed in many Mediterranean areas and other world regions, the time series of river discharge yield or water height are generally unavailable for long periods and/or large areas. In these cases, the historical approach is extremely useful, if not mandatory.

The time series approach is based on the statistical analysis of data concerning river discharge and climatic data, such as rainfall and temperature, performed using different statistical methods (Box and Jenkins, 1994; Goovaerts, 1997). Climatic data are used: (a) as a proxy for hydrological river data if such data are unavailable or show low frequency, spatial density, or quality, and (b) to analyse the effects of climate change on river discharge (Hannaford and Marsh, 2008; Brissette et al., 2003; Saint-Laurent et al., 2009). This approach can be applied from the 19th century to the present, according to the beginning of gauge networks in the majority of countries.

In this article, we present a methodology that uses both the historical and time series approaches and then we report the results of an application of the methodology that compared floods and rainfall trends in a study area in Southern Italy.

\section{Methodological approach}

The approach is based on the comparative analysis of a flood database and a climate database. The floods occurred over a long period, and the climate data characterising the same period were cross-checked to assess the effects, if any, of climatic trend on flood occurrence.

In the following sections, the characteristics of the two databases are briefly described, and the assumptions that needed to be made to perform the analyses are outlined. Finally, the steps for the comparative analyses of the databases are described.

\subsection{The flood database}

Historical hydrology is a well-defined research field that can provide data concerning floods that occurred in the preinstrumental period (Glaser and Stangl, 2003; Llasat et al., 2005; Brázdil and Kundzewicz, 2006; Adhikari et al., 2010). Knowing the long-term data series of past floods, the statistical analysis of return periods, frequency, seasonality and severity of floods can be improved (Agasse, 2003; Bartl et al., 2009), thus contributing to the assessment of the role of 
climatic variability on floods (Seidel et al., 2009). Based on descriptions available in the historical data, past floods can be classified according to scales expressing their relative magnitude (Barriendos Vallve and Martin Vide, 1998; Benito et al., 2004; Mudelsee et al., 2004; Rohr, 2006; Copien et al., 2008). This can be helpful in ungauged basins for which instrumental data are unavailable. Moreover, historical hydrology can gather data on extremely exceptional floods (Bartl et al., 2009; Balasch et al., 2010), which are difficult to analyse directly, because their recurrence period is longer than a human lifetime (Naulet et al., 2005).

Qualitative and quantitative analysis of flood variability over a period of centuries can include investigation of the driving climatic causes (Benito et al., 2003; Glaser and Stangl, 2004; Glaser et al., 2010), and specific floods can be studied to individuate the typical flood-generating atmospheric conditions (Böhm and Wetzel, 2006; Seidel et al., 2009). Comparative analysis of past and present monthly distribution of floods can be performed to detect both the presence of trends in the flood series (Benito et al., 2004; Glaser et al., 2010) and the changes in flood risk over the centuries (Mudelsee et al., 2004).

Even though historical data represent the only information available concerning floods that occurred in both ungauged and gauged basins during the pre-instrumental periods and can be used to estimate peak discharge, there are some limitations which have to be taken into account:

- The entire procedure is time consuming, and the research can never be considered complete because some archives may be inaccessible and others may have been affected by accidental document losses.

- Gaps may occur, generally affecting the oldest periods of the series and characterised by either a minor number of sources or a minor diffusion of information. Thus, an underestimation of the number of floods could affect the oldest periods. Other gaps could affect phenomena that occurred in unpopulated areas and did not induce damage; these may not be recorded because most sources provide more information on the damage than on the phenomena that caused it.

- The area actually affected is not exactly delimitable because, unless the document is a scientific article or a detailed technical report, maps of the impacted area are not supplied, even if details about the rivers affected and the points (place names) where flood damage occurred are frequently available. On a regional scale, to obtain a synoptic view of flood effects for comparison with climatic data, the basic geographical unit can be the municipal area. Actually, the effects of floods are cancelled by vegetation growth with the passing of seasons, and then only surveys conducted shortly after the flood can supply a delimitation of the impacted areas. Therefore, for investigation of floods that occurred many years ago, for periods in which aerial photography and satellite imaging technology were not yet developed, the municipal level of localisation should be considered acceptable, even if it is less than ideal.

To establish a flood database, the steps listed in Table 1 must be performed. Such a database can have several uses for the study of both flood processes and their impacts. For the present work, an index, called the Monthly Flood (MF), is defined as the total number of flood occurrences in each month; MF is used to characterise both the monthly recurrence and the spatial pattern of floods. Starting from monthly data, seasonal, annual, and/or multi-annual analyses can be realised (Benito et al., 2003).

\subsection{The climate database: data, elaborations, and cross-analysis with the flood database}

The assessment of the effects of climate variability on flood trend is based on the time series of monthly rainfall, the number of wet days, and temperature data. These data are freely available worldwide, with differences in length, density, and accuracy.

For the purposes of the present research, the analysis of climatic monthly data should be preferable with respect to those of shorter duration such as daily or hourly data. The use of daily data presents limitations which have to be taken into account, and these limitations are worse in the case of hourly data:

- Monthly rainfall data generally provide the maximum spatial density and largest observation period compared with daily data (e.g. in our database, the availability of data decreases from 128 to 70 solar years for monthly and daily data, respectively). In some regions, daily data are available only for short periods and/or a few gauges.

- Compared with monthly data, a database of daily data is about 30 times greater, and data processing is more complex and time consuming.

- The test of trend requires that both cyclic effects (e.g. seasonality) and autocorrelation are removed from the time series. If annual data are used, as in the proposed approach, the former condition is almost guaranteed. The use of daily data for annual trend analysis is not necessary.

- The use of monthly data represents a simple but necessary solution to the uncertainty affecting the exact time in which historical floods were observed. On a monthly basis, cross-analysis is possible.

The use of monthly data should be considered a disadvantage for those areas where floods are triggered by short-duration rainfall (a day or some hours). In these cases, the trend of short-duration rainfall should be taken into account in the 
Table 1. Main steps in the creation of the historical database concerning floods (Petrucci and Pasqua, 2008; Polemio and Petrucci, 2010).

\begin{tabular}{ll}
\hline Activities & Steps \\
\hline \multirow{3}{*}{ Data gathering } & 1. Analysis of existing databases \\
& 2. Selection of archives to look through \\
& 3. Planning historical research \\
& 4. Performing data collection \\
\hline Historical database construction & 1. Conversion of historical documents into text files \\
& 2. Disaggregation of data according to damaged sites \\
& 3. Chronological sorting of data \\
\hline
\end{tabular}

discussion of the effects of climate trend on flood occurrence. If a short-duration rainfall trend has not been described by previous studies, the changes of short-duration rainfall, either in terms of frequency distribution or exceptionality of annual peak values, should be analysed using the traditional approach of extreme value characterisation (Jenkinson, 1955). Since the time series of short-duration rainfall are generally shorter than climate monthly time series, the former trends will be qualitatively comparable with the latter trends.

The homogeneity of the selected climatic time series should be tested using the Craddock test or similar procedures (Craddock, 1979), and non-homogeneous data should be discarded. The time series or gauge location and number should be selected to obtain the maximum (or at least a sufficient) gauge density and spatial continuity, primarily of rainfall and secondarily of temperature, covering the largest period possible with the lowest number of data gaps.

A day with precipitation $\geq 1 \mathrm{~mm}$ is defined as a wet day. If the time series of monthly wet days $(D)$ is unpublished, the time series of daily precipitation $(P)$ can be used to calculate $D$. The precipitation intensity $(I)$ can be calculated as the average rain amount per wet day (e.g. if the rainfall of a month is equal to $44.4 \mathrm{~mm}$ and the number of wet days is 11 , in that month the precipitation intensity is $4.0 \mathrm{~mm} \mathrm{day}^{-1}$ ).

$P, D$, and $I$ describe characteristics of rainfall amount and distribution and so can be described as rainfall indexes.

The effects of temperature $(T)$ variability on runoff increase from humid to arid climates and change from season to season. For this reason, it is useful to define the type of climate and the characteristics of the climatic regime. The $P$, $D, I$, and $T$ regimes can be compared to the flood regime, as described below.

To assess the precipitation variability in the region, the monthly precipitation index $\operatorname{IP}_{1}(x, y)$ can be calculated for each month using Eq. (1):

$\operatorname{IP}_{1}(x, y)=\frac{\sum_{i=1}^{n} \operatorname{MP}_{i}(x, y)}{\sum_{i=1}^{n} \operatorname{AMP}_{i}(x)} 100-100$

where $x$ indicates the month $(x=1,2, \ldots$, to 12 , starting from the first month of the hydrological year), $y$ is the year (starting from the beginning of the monitoring period), $\mathrm{MP}_{i}$ is the monthly precipitation at gauge $i$ of the month $(x, y)$ and
$\mathrm{AMP}_{i}$ is the average monthly precipitation of month $x$ at gauge $i$, with $i=1,2, \ldots, n$, where $n$ is the number of available gauges in the month $(x, y)$.

Similarly, the monthly, bi-monthly, tri-monthly, and ... $m$-monthly indexes $\operatorname{IP}_{1}(x, y), \operatorname{IP}_{2}(x, y), \ldots, \operatorname{IP}_{m}(x, y)$, with $m=1,2, \ldots, 12$, can be defined using Eq. (2):

$\operatorname{IP}_{m}(x, y)=\frac{\sum_{j=z-m}^{z} \sum_{i=1}^{n} \operatorname{MP}_{i, j}(x, y)}{\sum_{j=z-m}^{z} \sum_{i=1}^{n} \operatorname{AMP}_{i, j}(x)} 100-100$

where $z$ is the position number of the months, in progressive order, starting from the first month of the first hydrological year and $\operatorname{IP}_{m}(x, y)$ are rainfall values observed in the month $z$ and in the $m-1$ previous months, where $m$ is the duration of the considered index. Using this dimensionless index, a unique precipitation time series can be applied to the whole region. Defined based on monthly duration, the index duration should extend 12 months at least. $\operatorname{IP}_{12}(12, y)$ accounts for the rainfall values observed during the whole hydrological year $y$, so it can be defined as $\operatorname{IP}(y)$, the yearly precipitation index of the year $y$.

Thanks to the $\operatorname{IP}_{m}(x, y)$ definition, occasional gaps in single rainfall time series do not create difficulties in the method application and do not require approximations or missing data extrapolations. Because $\operatorname{MP}_{i}(x, y)$ is positive or equal to zero, the $\operatorname{IP}_{m}(x, y)$ minimum value ranges from a theoretical -100 , due to no rainfall at each of the available $n$ gauges in the selected $m$-month period, to an undefined positive value that can be reached due to exceptional rainfall events that occurred during the selected $m$ months. Negative values of $\operatorname{IP}_{m}(x, y)$ indicate that the rainfall was lower than average over the whole area, while positive values indicate the contrary. The range should become narrower as $m$ increases; this effect is due to the minimum increase and (especially) the maximum decrease of $\operatorname{IP}_{m}(x, y)$.

Similar indexes $\operatorname{IT}_{m}(x, y), \operatorname{ID}_{m}(x, y)$, and $\mathrm{II}_{m}(x, y)$ can be defined for the parameters $T, D$, and $I$.

The interpretations of the range and variability of $\operatorname{ID}_{m}(x, y)$ and $\mathrm{II}_{m}(x, y)$ should be similar to the interpretations of $\operatorname{IP}_{m}(x, y)$. Because the monthly temperature can be negative, and the variability is different and lower than the monthly rainfall parameters, the $\operatorname{IT}_{m}(x, y)$ range should be 
the narrowest and almost symmetrical with respect to zero, whatever value of $m$ is considered.

If $\operatorname{MF}(x, y)$ is the monthly flood number recorded during the month $(x, y)$, then $\operatorname{IF}_{m}(x, y)$, the $m$-monthly index of flood occurrence, is assessed using the Eq. (3):

$\operatorname{IF}_{m}(x, y)=\frac{\sum_{j=z-m}^{z} \sum_{i=1}^{n} \operatorname{MF}_{i, j}(x, y)}{\sum_{j=z-m}^{z} \sum_{i=1}^{n} \operatorname{AMF}_{i, j}(x)} 100-100$

where $\mathrm{AMF}_{i}$ is the Average Monthly number of Floods of the month $x$ in the cell $i$, with $i=1,2, \ldots, n$, where $n$ is the number of cells into which the study area is divided. The total $\operatorname{AMF}_{i}(x)$, for $i=1,2, \ldots, n$, calculated for each month, defines the flood regime.

The interpretation of the range and variability of $\operatorname{IF}_{m}(x, y)$ is similar for $\operatorname{IP}_{m}(x, y)$, even if the range should be much wider, due to the effects of peak values of each time series.

The five groups of indexes (IF, IP, IT, ID, and II) permit the comparison of flood variability with climate variability throughout the time period, considering durations ranging from one month to a whole hydrological year. Trend and cross-correlation analyses should be the basic methods used to analyse these time series (Brockwell and Davis, 1987).

The simplest way to quantify the trend slope is to use (straight) linear regression analysis. Linear regression provides an estimation of the trend slope (the slope, or angular coefficient $a$, can be calculated by least square linear fitting) and confidence interval, and it quantifies the goodness of fit, even if it is greatly affected by both outliers and cyclic data. To solve these uncertainties, the statistical reliability of detected trends should be tested; an affordable choice is to use the non-parametric Mann-Kendall test (Mann, 1945; Kendall, 1975; Hirsch et al., 1982, Polemio and Casarano, 2008; Wahlin and Grimwall, 2010). If the quantitative assessment of the slope trend is particularly relevant, the Sen method should be used (Thiel, 1950; Sen, 1968).

\section{The Calabria case study}

Calabria, the southern-most Italian region (Fig. 1), is a peninsula with a surface of $15230 \mathrm{~km}^{2}$, a perimeter of $738 \mathrm{~km}$, and mean and maximum altitudes of 418 and $2266 \mathrm{~m}$ above sea level, respectively. Almost $90 \%$ of the regional territory shows topographic relief, and $10 \%$ is represented by coastal and fluvial plains; $93.5 \%$ of the region is lower than 1300 $\mathrm{m}$ a.s.l. From an administrative point of view, the region is divided into five provinces and 409 municipalities. The population density $\left(133 \mathrm{inh}^{-2}\right)$ is lower than the national value (198 inh $\mathrm{km}^{-2}$ ) (ISTAT, 2003).

The region is made up of a stack of allochthonous terrains (from Palaeozoic to Jurassic), composed of crystalline rocks (mainly gneiss and granite) that were derived from both continental and oceanic crusts and stacked during the middle Miocene (Tortorici, 1982) over the carbonate units of northern Calabria (Ogniben, 1973). During the emplacement of

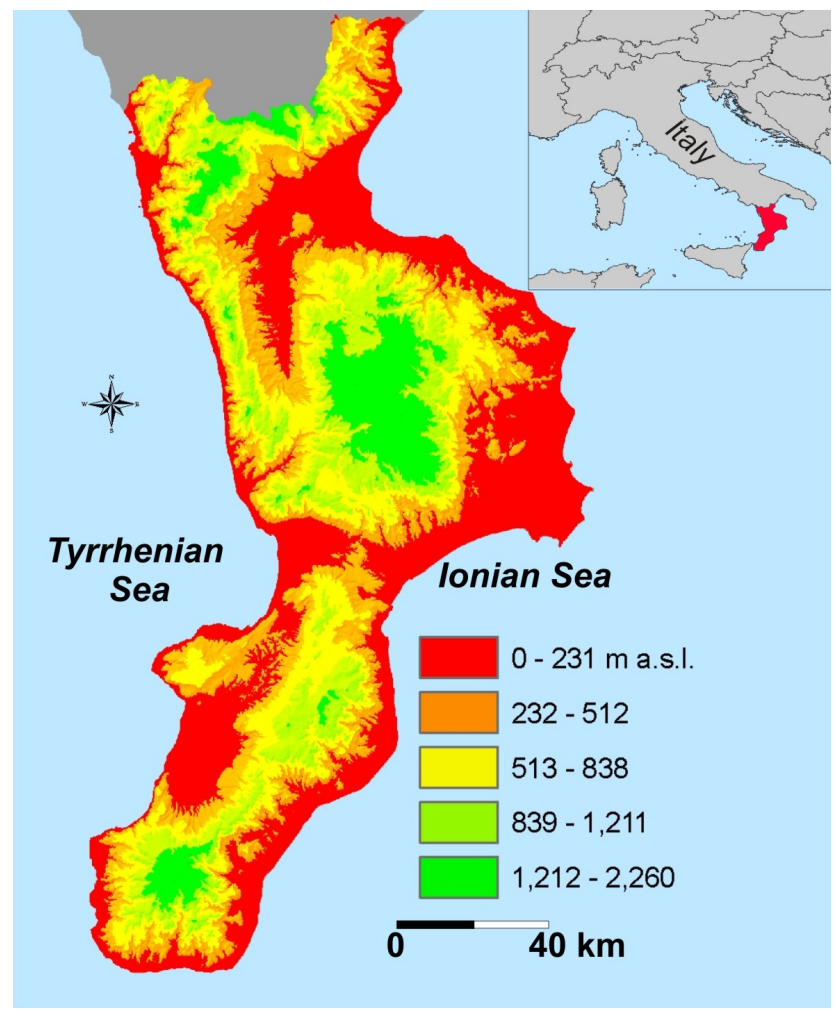

Fig. 1. Digital elevation model of the Calabria region and its location on the Italian peninsula.

terrains and onwards, the Neogene's tectonic melange and flysch built a substratum that underwent extension because of uplift that began in the Quaternary and is still active. The rapid neo-tectonic uplifting shaped the form of the region, which looks like a platform with a round-shaped summit bounded by steep flanks. This shape led to the creation of a river network mainly made of ephemeral streams, named fiumara, widely observed in southern Italy. Actually, $55 \%$ of the regional area is covered by fiumara basins (less extended than $200 \mathrm{~km}^{2}$ ), while $45 \%$ is occupied by both the main basin of the region, named Crati River $\left(2440 \mathrm{~km}^{2}, 16 \%\right.$ of the regional surface) and other eight major basins.

Larger rivers rise from the innermost and highest reliefs of the region, while fiumaras originate from the steep flanks of regional reliefs and reach the sea along steep, short and narrow paths which enlarge abruptly when they reach the coastal plan, where they create wide, anastomosed river beds. These beds can be wider than one kilometre: during summer they can be completely dry, but the major floods can flow through the entire section, re-distributing the bed load and changing the geometry of the channels' network (Viparelli, 1972). Due to its high neo-tectonic uplift $(1000 \mathrm{~m})$ (Ibbeken and Schleyer, 1991), in fact, Calabria is a powerful source of sediments: both erosion processes and landslides represent the sources of the huge amount of debris transported by major floods. The active section of the river frequently changes 
its position as an effect of floods. Because of the seasonal migration of river channels through the river bed, it is almost impossible to install a gauge that works properly, and then discharge data are unavailable.

Because of the mountainous morphology of the region, the population density is lower in the mountainous municipalities and higher in the coastal and river plains, where major cities, transport facilities, agricultural and industrial settlements have been settled. The high density of vulnerable elements in the narrow river and coastal plains, just in the places where fiumara floods concentrate their destructive power, amplifies the relevance of this research.

\subsection{The FLO-Cal database}

A part of the data concerning floods were obtained from ASICal (Aree Storicamente Inondate in Calabria, 2010), a database of landslides and floods that occurred in Calabria during the past centuries. To fill some space/time gaps in the series, further historical studies were conducted. In this way, a new database, called FLO-Cal, which contains the floods that occurred in Calabria between September 1880 and August 2007, was created.

The data were collected by hydrological years (from 1 September to 31 August), which were conventionally named as the solar year that began with September (i.e. the hydrological year 1924 spans the time from 1 September 1924 to 31 August 1925). FLO-Cal records were sorted chronologically and by municipality, with each record corresponding to a flood event affecting a certain municipality on a certain date.

FLO-Cal contains 2173 records concerning floods that occurred in the analysed $127 \mathrm{yr}(1880-2007)$. Because of the type of historical documents from which the data were collected (mostly reimbursement requests and newspaper articles), FLO-Cal is sufficiently reliable and mainly includes floods that caused damage. Basically, because of both the regional distribution of vulnerable elements and the river network characteristics, flood damage affected the terminal portion of both fiumaras and rivers. Damaged elements are mainly: (a) towns and seaside villages; (b) main regional roads and railways, which run close to the coast due to the mountainous regional characteristics, thus crossing all the rivers in their terminal reach; (c) cultivated fields and rural settlements established in these relatively large plains near the riverbed in order to easily catch water for irrigation purposes.

The mean number of floods per year was 17 , and the maximum number of floods was recorded in the hydrological year 1953 (177 cases, $8 \%$ of the total number of records) (Fig. 2a). For the first decades of the series (Fig. 2b), the scarcity of data may have been related to the low number of information sources available in that period. For 8 yr $(6 \%$ of the total number of analysed years), no flood data were available, and in $11 \mathrm{yr}(9 \%)$, the number of floods recorded was
1. When the study period was divided into decades (Fig. 2b), the mean number of floods per decade was 167 , and the highest number of cases (506 cases, $23 \%$ ) was recorded in the decade 1951-1960, during which three severe DHEs affected Calabria (Petrucci et al., 2009). The minimum number of floods occurred in the decade 1880-1890 (17 cases, 1\%).

The total number of floods recorded in each municipality was used to perform a basic spatial analysis (Fig. 3a). The highest values were found for municipalities located in north-eastern Calabria, along the Sibari plain. This is the widest plain in Calabria; it was created by sedimentation of the Crati River and adjacent fiumaras and it is intensively used for agricultural purposes. The presence of both valuable cultivations and urban settlements ensured the recording of a long series of damaging floods.

In $127 \mathrm{yr}$, the mean number of floods per municipality was 5 ; a low number of municipalities ( $13 \%$ of the total) had no floods in the study period, while the majority of municipalities $(80 \%)$ had a mean number of floods between 1 and 15. The maximum number of floods per municipality was 83, which occurred in Reggio Calabria (the red area on the SW coastal sector of the region): here, flood damage was caused by fiumaras: eleven of this kind of river pass through the municipalities and nine cross the town. Historical data concerning major floods describe cases in which, because of the bed load, "first floors of the houses became basements".

The municipality map of flood recurrence can be obtained from Fig. 3a, by dividing the class values of the legend by $127 \mathrm{yr}$ (the study period duration). The highest recurrence value was 0.65 floods $\mathrm{yr}^{-1}$, or 1 flood every $1.53 \mathrm{yr}$; the mean recurrence value was 0.04 floods $\mathrm{yr}^{-1}$. The maximum total number of floods and recurrence values were mainly observed in coastal areas.

When the density of total flood numbers per municipality was considered $\left(0,15\right.$, and 287 floods $\times 100 \mathrm{~km}^{-2}$ were the minimum, mean, and peak values, respectively), it was evident that the municipality areas had only secondary effects on the spatial distribution of the flood number (Fig. 3b). In the inland and mountainous municipalities, which generally had lower population densities, the total number of floods was low; a slight increase was observed along the southeast sector of the region. The total flood number per population density (Fig. 3c) $\left(0,6\right.$, and 63 floods $\times 100 \mathrm{~km}^{2}$ inhabitants ${ }^{-1}$ were the minimum, mean, and peak values, respectively) data showed that the region appeared to be almost homogeneous and dominated by classes with significant values of floods per population density. More generally, the highest number of cases were recorded in the densely populated municipalities located near the coasts, especially at the mouths of rivers, as highlighted in previous studies (Petrucci and Pasqua, 2008; Petrucci et al., 2010b).

On a monthly basis, November was characterised by the greatest amount of floods $(22.1 \%)$, followed by October $(17.8 \%)$ and December $(16.5 \%)$, while the lowest value $(0.9 \%)$ pertains to July. On a seasonal basis, the highest 
A

\begin{tabular}{|c|c|c|c|c|c|c|c|c|c|c|c|c|c|c|c|c|c|}
\hline Year & $\begin{array}{l}\text { N. of } \\
\text { data }\end{array}$ & Year & $\begin{array}{l}\text { N. of } \\
\text { data }\end{array}$ & Year & $\begin{array}{l}\text { N. of } \\
\text { data }\end{array}$ & Year & $\begin{array}{l}\text { N. of } \\
\text { data }\end{array}$ & Year & $\begin{array}{l}\text { N. of } \\
\text { data }\end{array}$ & Year & $\begin{array}{l}\text { N. of } \\
\text { data }\end{array}$ & Year & $\begin{array}{l}\text { N. of } \\
\text { data }\end{array}$ & Year & $\begin{array}{l}\text { N. of } \\
\text { data }\end{array}$ & Year & $\begin{array}{l}\text { N. of } \\
\text { data }\end{array}$ \\
\hline 1880 & 3 & 1895 & 3 & 1910 & 4 & 1925 & 21 & 1940 & 9 & 1955 & 22 & 1970 & 8 & 1985 & 17 & 2000 & 42 \\
\hline 1881 & 2 & 1896 & 10 & 1911 & 3 & 1926 & 4 & 1941 & 7 & 1956 & 11 & 1971 & 27 & 1986 & 16 & 2001 & 12 \\
\hline 1882 & 1 & 1897 & 0 & 1912 & 3 & 1927 & 22 & 1942 & 11 & 1957 & 84 & 1972 & 135 & 1987 & 37 & 2002 & 41 \\
\hline 1883 & 0 & 1898 & 16 & 1913 & 2 & 1928 & 3 & 1943 & 0 & 1958 & 17 & 1973 & 19 & 1988 & 15 & 2003 & 33 \\
\hline 1884 & 0 & 1899 & 1 & 1914 & 0 & 1929 & 24 & 1944 & 24 & 1959 & 68 & 1974 & 23 & 1989 & 12 & 2004 & 43 \\
\hline 1885 & 3 & 1900 & 2 & 1915 & 2 & 1930 & 47 & 1945 & 5 & 1960 & 10 & 1975 & 16 & 1990 & 20 & 2005 & 15 \\
\hline 1886 & 0 & 1901 & 1 & 1916 & 5 & 1931 & 1 & 1946 & 15 & 1961 & 7 & 1976 & 59 & 1991 & 4 & 2006 & 5 \\
\hline 1887 & 0 & 1902 & 5 & 1917 & 3 & 1932 & 15 & 1947 & 1 & 1962 & 7 & 1977 & 4 & 1992 & 3 & 2007 & 2 \\
\hline 1888 & 3 & 1903 & 23 & 1918 & 1 & 1933 & 47 & 1948 & 12 & 1963 & 11 & 1978 & 11 & 1993 & 8 & & \\
\hline 1889 & 2 & 1904 & 9 & 1919 & 1 & 1934 & 18 & 1949 & 17 & 1964 & 18 & 1979 & 9 & 1994 & 15 & & \\
\hline 1890 & 1 & 1905 & 40 & 1920 & 16 & 1935 & 35 & 1950 & 46 & 1965 & 19 & 1980 & 19 & 1995 & 42 & & \\
\hline 1891 & 1 & 1906 & 41 & 1921 & 18 & 1936 & 14 & 1951 & 64 & 1966 & 21 & 1981 & 6 & 1996 & 46 & & \\
\hline 1892 & 1 & 1907 & 3 & 1922 & 0 & 1937 & 3 & 1952 & 23 & 1967 & 2 & 1982 & 15 & 1997 & 6 & & \\
\hline 1893 & 0 & 1908 & 4 & 1923 & 12 & 1938 & 5 & 1953 & 177 & 1968 & 7 & 1983 & 15 & 1998 & 5 & & \\
\hline 1894 & 1 & 1909 & 1 & 1924 & 6 & 1939 & 45 & 1954 & 16 & 1969 & 23 & 1984 & 46 & 1999 & 11 & & \\
\hline
\end{tabular}

Total number of flood data: $\mathbf{2 1 7 3}$

Mean number of data per year: 17

B

\begin{tabular}{|c|c|c|c|c|c|c|c|c|c|c|c|c|c|c|}
\hline Decade & $\begin{array}{l}8 \\
\stackrel{8}{\infty} \\
\infty \\
\vdots \\
\infty \\
\infty \\
\infty\end{array}$ & $\begin{array}{l}\frac{8}{8} \\
\frac{1}{1} \\
\frac{1}{0}\end{array}$ & $\frac{0}{\frac{0}{9}}$ & $\begin{array}{l}\text { } \\
\frac{\sigma}{\sigma} \\
\frac{1}{5} \\
\frac{1}{\sigma}\end{array}$ & 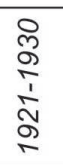 & $\begin{array}{l}\frac{9}{\sigma} \\
\stackrel{5}{a} \\
\frac{1}{\infty} \\
\frac{1}{n}\end{array}$ & 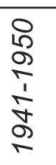 & $\begin{array}{l}8 \\
\stackrel{0}{0} \\
\frac{1}{1} \\
\frac{1}{5} \\
0\end{array}$ & 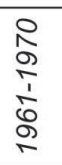 & 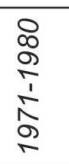 & 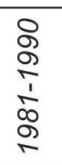 & 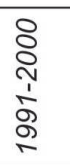 & 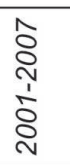 & $\begin{array}{l}\mathbb{8} \\
\frac{\pi}{0} \\
\stackrel{\alpha}{\alpha}\end{array}$ \\
\hline N. of data & 17 & 33 & 130 & 34 & 126 & 221 & 125 & 506 & 123 & 315 & 205 & 179 & 155 & 167 \\
\hline Data as $\%$ of total & 1 & 2 & 6 & 2 & 6 & 10 & 6 & 23 & 6 & 15 & 9 & 8 & 7 & \\
\hline
\end{tabular}

Fig. 2. Number of flood data and annual distribution. (A): number of flood data collected for each year of the study period. (B): Data distribution per decade.

percentages of data concerns autumn $(46 \%)$, followed by winter (39\%) spring (11\%) and summer (3\%).

Analysing the flood occurrences in terms of frontal analysis, the hydro-climatological patterns which triggered the severest cases were individuated. A wide majority of cases were caused by the persistent effects of perturbations preceded by the appearance of low-pressure fields in two different areas located westwards of the region (Hirschboeck et al., 2000; Petrucci and Polemio, 2009). The former low-pressure was generally located in north-western Africa, Spain or between these areas, while the latter was located northward, in an area bounded by the western Mediterranean Sea, France, Spain or the northern Atlantic. The former barometric depression ensured the inflow of African masses of warm air, while the latter permitted the inflow of very cold air masses. In this way, approximately at the centre of the Mediterranean, a cold front met a warm one, causing strong and lasting storms. These results were obtained by studying the damaging hydrogeological events that occurred from 1921 to 2005 , for which all necessary data were available (Petrucci and Polemio, 2009). This study was continued, enlarging the study period and including a series of climatic variables to highlight the existence of climatic modifications on flood occurrence.

\subsection{The CLIMATE-CAL database}

Starting from an existing climatic database created to study the climate change in southern Italy (Polemio and Casarano, 2008), a climatic database for Calabria, named CLIMATECal, was built. CLIMATE-Cal has collected monthly time series of both rainfall and temperature since 1821 and contains the monthly and daily data for 263 Calabria gauges (155 daily time series). Eliminating non-homogeneous data, 65 gauges were selected from CLIMATE-Cal to provide reliable elevation coverage of the study area (between 3 and $1300 \mathrm{~m}$ a.s.1.) for the period 1880-2007. In this way, both adequate gauge density and spatial continuity were obtained (mainly for rainfall and secondly for temperature) for a long portion of the study period (Fig. 4); the minimum, mean, and peak values of annual number of available gauges were respectively equal to 5 (observed sometime in the first thirty years), 45, and 65. Forty-five of the selected gauges (located at altitudes between 5 and $1300 \mathrm{~m}$ a.s.1.) were also equipped for temperature measurement. Precipitation, wet days, and temperature data published by public institutions were used to cover the period from 1880 to 2007 (the main source of data was the Calabria Region Office). The temperature data suffered some gaps from 1907 to 1920 and for 18 months 

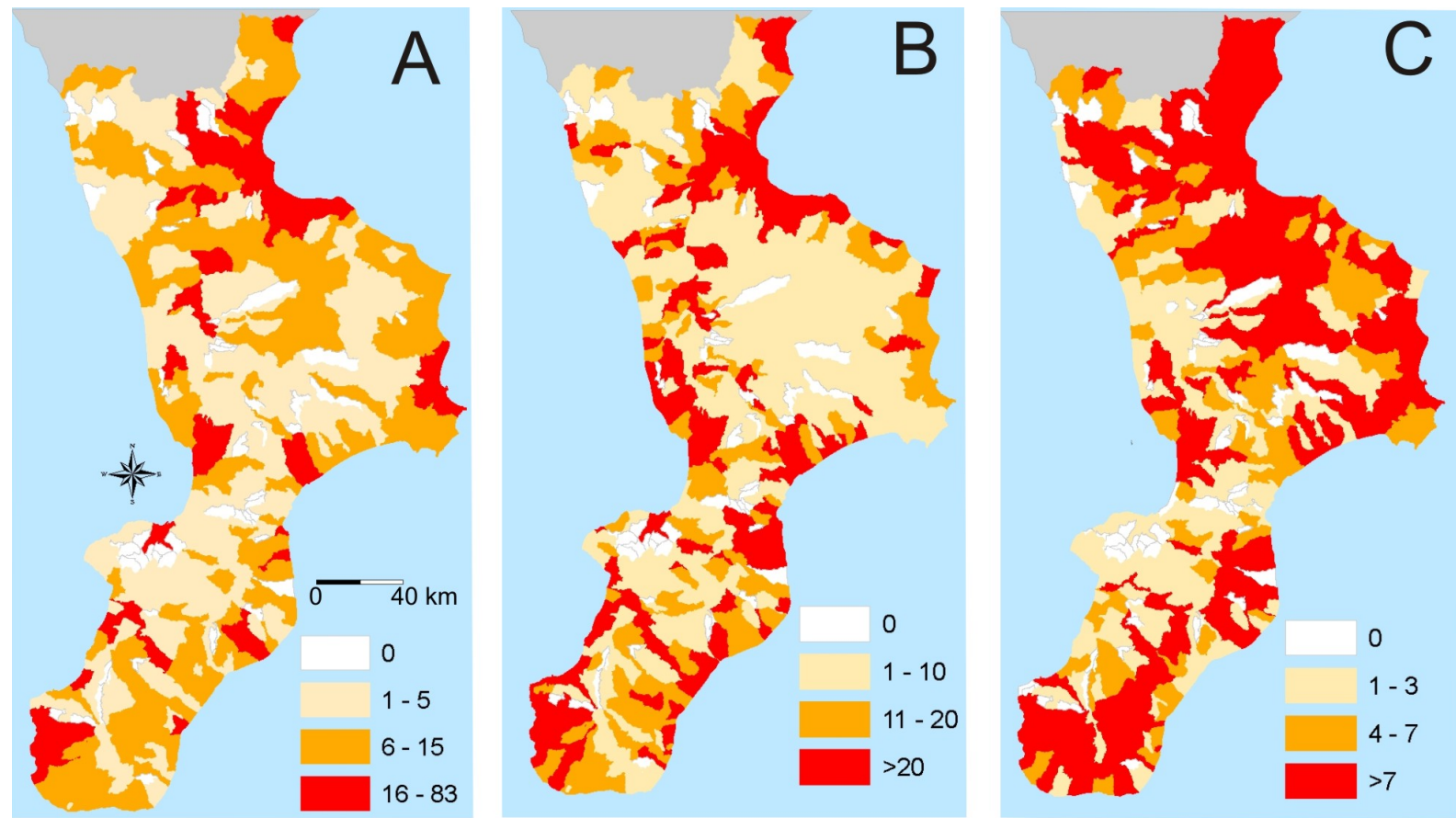

Fig. 3. Maps of total municipality flood number. (A) Total number of floods (TNF); (B) density: TNF divided by municipality area (TNF $100 \mathrm{~km}^{-2}$ ); (C) TNF per population density (TNF $100 \mathrm{~km}^{2}$ inhabitants ${ }^{-1}$ ).

during the period 1975 to 1982 . Until 1919, the institutions publishing data used to define a wet day as a day in which precipitation was greater than zero (hereinafter, the number of wet days concerning that period is termed $D_{\text {old }}$ ); since 1920, the standard definition has been used.

To remove the effect of this non-homogeneity, a daily precipitation dataset of 155 time series (from 1921 to 1990) was used, and for each month/gauge, $D$ and $D_{\text {old }}$ were assessed. A monthly linear multiple regression was defined by setting $P$ and $D_{\text {old }}$ as independent variables and $D$ as the dependent variable (regression coefficient equal to 0.99 ), thus assessing a preliminary value of $D$ for the period 1880 to 1919 . The next step was a logical validation, taking into account that $D$, in each month, should be either $\leq D_{\text {old }}$ and either less than or equal to the integer $P(\mathrm{~mm})$.

Using the selected time series, the climate in Calabria appeared to be typically Mediterranean, characterised by hot dry summers and long wet periods that occurred both in autumn and winter and could last until the early spring (Fig. 5). The mean annual precipitation ranged from 495 to $1775 \mathrm{~mm}$, and the regional spatial average was about $1100 \mathrm{~mm}$. The spatial variability of precipitation was mainly due to the altitude effect (Figs. 1 and 4) and secondly to the distance from the western coast; at equal altitudes, the precipitation was higher on the western side because the main perturbations generally moved from west to east (Petrucci and Polemio, 2009). The annual mean for $D$ ranged from 51 to 110 (86 was the regional average), while for $I$ it ranged from 7.2 to $15.9 \mathrm{~mm} \mathrm{day}^{-1}\left(11.2 \mathrm{~mm} \mathrm{day}^{-1}\right.$ was the regional average), and for $T$ it ranged from 8.9 to $18.3^{\circ} \mathrm{C}\left(15.7^{\circ} \mathrm{C}\right.$ was the regional average). The spatial variability of these variables was mainly correlated with the altitude. The effect of meteorological frontal systems on annual spatial distributions of rainfall characteristics, in terms of $P, D$ and $I$, seems relevant.

In the region, the $P$ regime was almost homogeneous; rainfall started to increase from September up to the monthly maximum in December, and then decreased; minimum rainfall was recorded in July (Fig. 5). Similar trends were observed for $D$ and $I$; for I the maximum was observed in November. On the other hand, $T$ decreased from September to the minimum in January and then increased up to the August peak.

The ranges of the rainfall indexes $(P, D$, and $I)$ were fairly similar: the minimum varied from -55 to -34 , the peak ranged from 45 to 50 , and the range varied from 83 to 104. The yearly index of $T$ was narrower as it varied from -6 to 12 (range equal to 18). Due to the frequent occurrence of both single-flood years and years with hundreds of floods, the range of IF was one order of magnitude greater than the rainfall indexes. Figure 6 shows the yearly time series of $F$ and climate indexes and their linear trends. The $F$ trend was positive (the angular coefficient of the straight regression line trend, $a_{F}$, was 0.188$)$; the trend was statistically extremely significant $(p<0.001)$ on the basis of the Mann-Kendall test. A second-order polynomial trend line highlighted two different trends: from 1880 to 1971 the trend increased and thereafter the slope slightly decreased until 2007. 

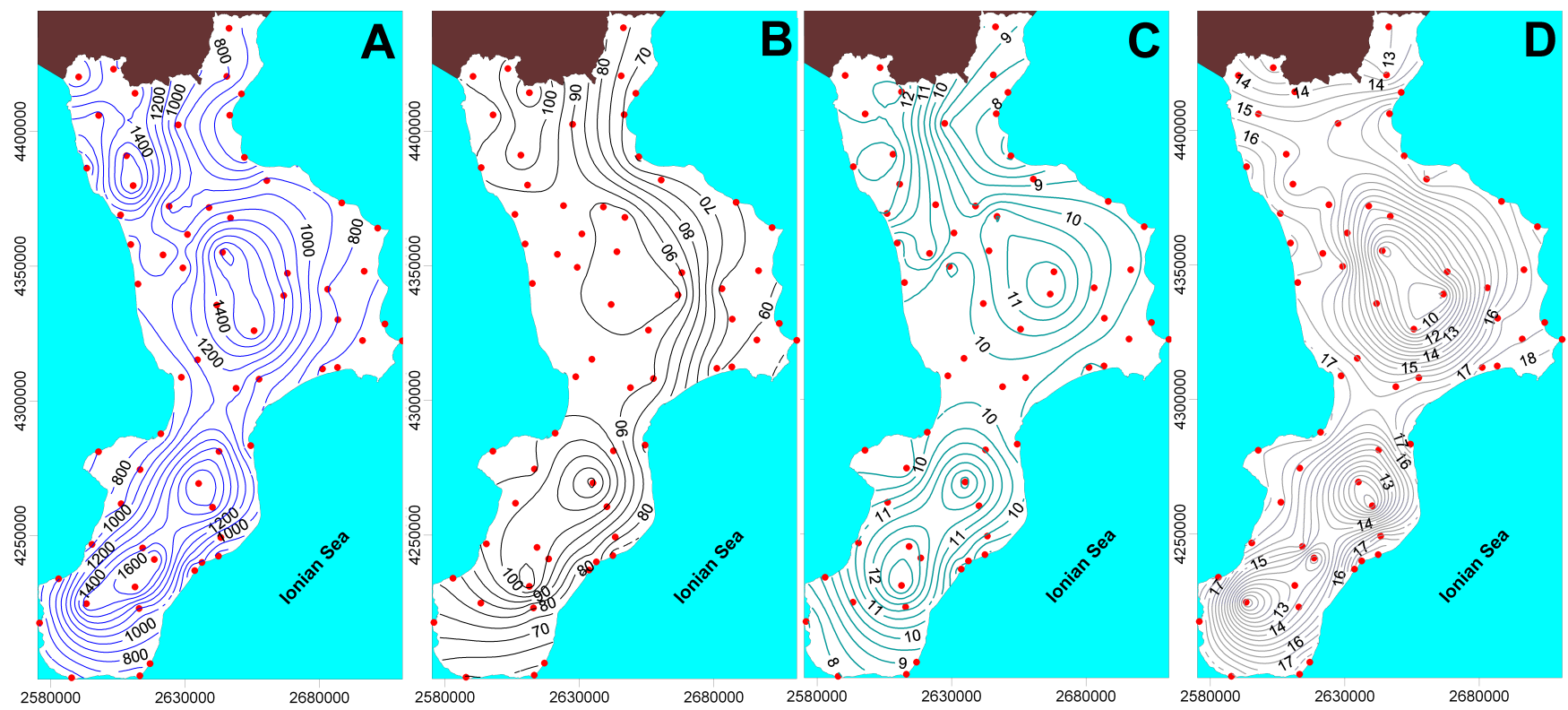

Fig. 4. Map of selected gauges (dots) and contour lines of the mean annual values of precipitation (A, mm), wet days (B), precipitation intensity $\left(\mathbf{C}, \mathrm{mm}^{\mathrm{day}}{ }^{-1}\right)$, and temperature $\left(\mathbf{D},{ }^{\circ} \mathrm{C}\right)$.

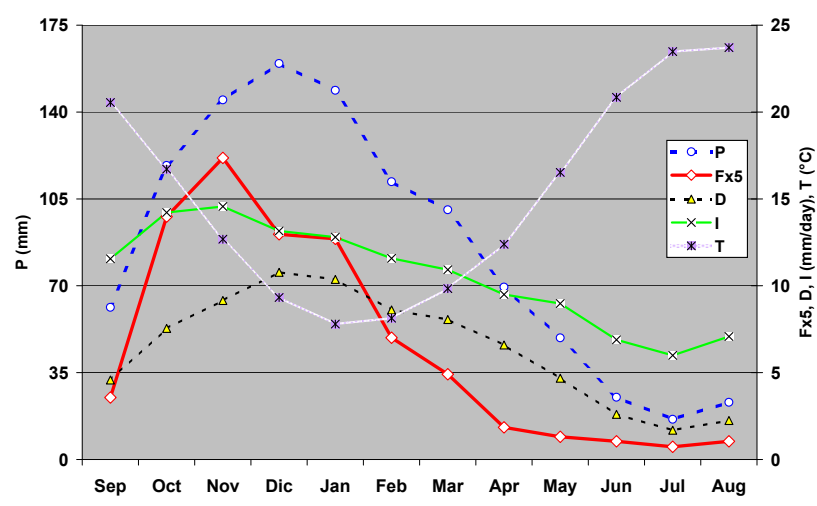

Fig. 5. Regime of precipitation $(P)$, floods $(F)$, wet days $(D)$, precipitation intensity $(I)$, and temperature $(T)$.

The IP trend slightly decreased throughout the period ( $a_{\mathrm{IP}}$ was -0.062) even if it showed a low statistical significance $(p<0.1)$. The II trend was almost constant and not statistically significant, while the ID trend was decreasing $\left(a_{\mathrm{ID}}\right.$ was equal to -0.105$)$ and statistically significant $(p<0.05)$.

Presently, it is well known that the temperature trend is increasing on both regional and global scales, so it is not surprising that the IT trend was positive ( $a_{\mathrm{IT}}$ was 0.024$)$. The detected temperature trend was statistically significant $(p<0.05)$.

Previous research has highlighted that the decreasing rainfall trend of the period from autumn to winter, in which the floods were concentrated, was higher than the annual trend (Brunetti et al., 2004; Polemio and Casarano; 2008; Polemio and Petrucci, 2010). The availability of rainfall for runoff, in terms of actual rainfall, was further reduced because of the increasing evapotranspiration due to the positive trend of temperature observed in each season.

The trend of daily rainfall in Calabria for the period 19232006 was discussed by Brunetti et al. (2011) and the annual trend of high-daily rainfall classes (percentiles 90, 95, and $99 \%$ ) was statistically significant and very negative or decreasing (in some areas the decrease in these classes was greater than $20 \%$ throughout the whole period). The annual trend of low-daily rainfall classes was positive, even if statistically significant only in some areas. The discussion of short-duration rainfall trend presented by Brunetti et al. (2011) is consistent with the knowledge acquired on monthly data: rainfall was decreasing, and this was due to a decreasing trend of both wet days and high-rainfall wet days. The combined effect of these trends with the trend of $I$, defined as the average rain amount per wet day, was almost negligible.

Thus, the results on climate trend presented in this work are consistent with the knowledge previously acquired on the whole country, for southern Italy and for the Calabria region. In addition, the above-mentioned studies analysed shorter study periods than those used in our work, where the beginning of the study period was moved about forty years backwards. Even with a longer study period, the results were confirmed. 

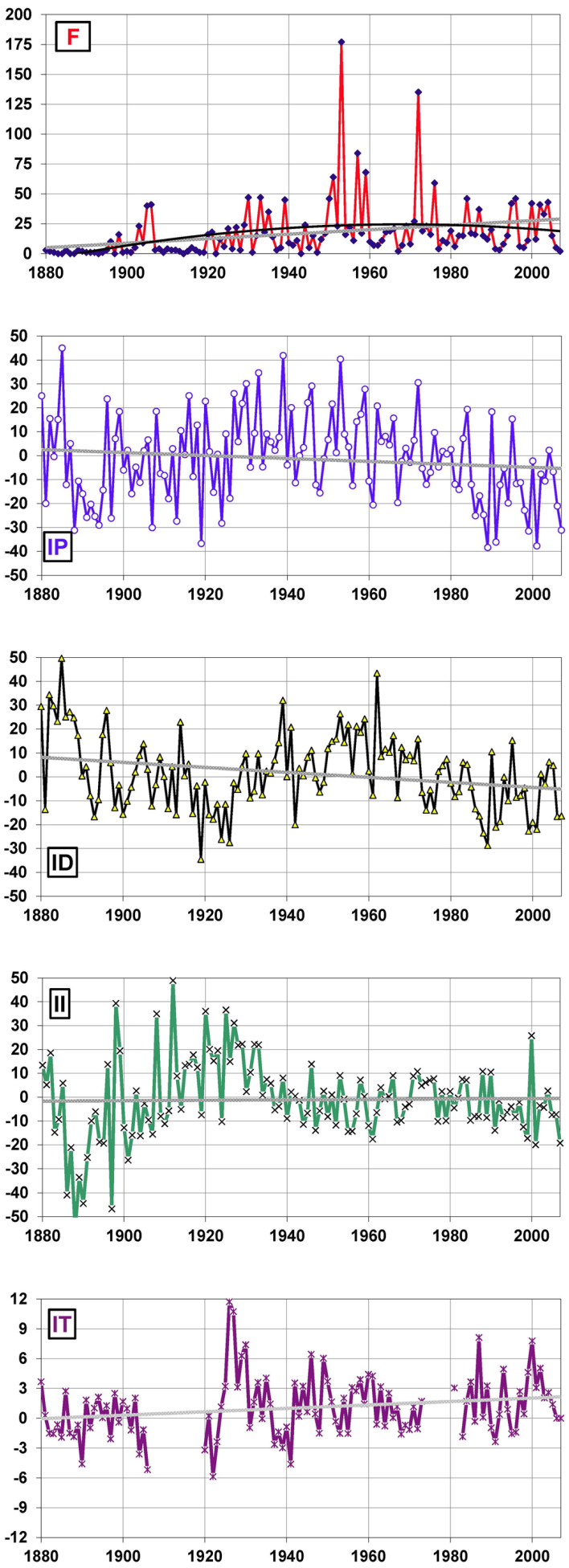

Fig. 6. Linear trend and time series of floods $(F)$ and yearly indexes of precipitation (IP), wet days (ID), precipitation intensity (II), and temperature (IT). The linear trend is the grey line in each diagram; a polynomial trend line, shown in black, is added for $F$.

\subsection{Cross-analysis and discussion}

In terms of mean hydrologic year, a very good correlation is mainly observed between floods and precipitation intensity and secondly between floods and rainfall and wet days. The correlation between floods and temperature is inverse and particularly significant between February and November (Fig. 5).

Moving to monthly values, the time series of the indexes $\mathrm{IL}_{m}, \mathrm{IP}_{m}, \mathrm{ID}_{m}, \mathrm{II}_{m}$, and $\mathrm{IT}_{m}$ were calculated for $m=1,2,3,6$, and 12 . For the sake of brevity, some statistical values of these time series are summarised in Table 2 (for $m$ equal to 1 and 3 ).

A good correlation between the monthly flood number and the selected variables was observed (Fig. 5). The peaks for $P, D$, and $I$ were reached between November and December, as for $F$. In statistical terms, it was useful to determine the cross-correlation coefficient $\mathrm{CC}^{l}$ between $F$ and $P, D$, and $I$; the lag $l=1,2, \ldots . \mathrm{CC}^{0}$ was equal to $0.91,0.82$ and 0.91 for $P, D$, and $I$, respectively. The correlation with $T$ was weaker and negative $(\mathrm{CCT}=-0.58)$, which was reasonable. For each variable, $\mathrm{CC}$ decreased as $l$ increased and became statistically not significant for $l>3$. Thus, in terms of mean hydrological year, the variability of the flood number was mainly described by precipitation and progressively less by precipitation intensity, wet days, and temperature.

Analysis of the yearly time series confirmed the results for the mean monthly values (Table 3 ). In this case, the results were statistically identical if either $F$ (defined as the yearly total number of floods in each cell of the region) or IF were considered. $\mathrm{CC}^{0}$ decreased from 0.44 to 0.19 for IP and II, respectively. The correlation with IT was low and not significant. For each variable, CC decreased as $l$ increased. IP was highly correlated with ID and II; this result should be considered if a forecasting model for $F$ is defined using IP, ID, and/or II as independent variables.

A deeper discussion of the annual variability highlights a rough relationship between flood recurrence and the succession of wet and dry periods. A clear example was observed in the fifties, during which both an anomalous high value of floods and high values of $P$ and $D$ were observed (Figs. 2 and 6). This relationship is less evident in other periods, as in the thirties or in the first decade of the twenties century, a dry period. Disaggregating the whole period, the more significant parameters for the flood occurrence variability seem $P$ and $D$.

In any case, the $F$ (or IF) linear trend could not be justified by the trends of IP, ID, II, and IT (Fig. 6). In fact, the combined effects of: (a) decreasing precipitation and wet days, (b) the nearly constant precipitation intensity, and (c) the increasing temperature trend could not have caused an increase of floods in an area characterised by a semi-arid and temperate climate. It seems that in Calabria, the climate trend may have resulted in climatic conditions that were unfavourable to increases in flood occurrence. When the polynomial $F$ trend 
Table 2. Statistics of the monthly time series of floods $(F)$ and the indexes of floods (IF), precipitation (IP), wet days (ID), precipitation intensity (II), and temperature (IT). $m$ : 1-month time series, $3 m$ : 3-month time series.

\begin{tabular}{|c|c|c|c|c|c|c|c|c|c|c|c|c|}
\hline & \multicolumn{2}{|c|}{$F$} & \multicolumn{2}{|c|}{ IF } & \multicolumn{2}{|c|}{ IP } & \multicolumn{2}{|c|}{ ID } & \multicolumn{2}{|c|}{ II } & \multicolumn{2}{|c|}{ IT } \\
\hline & $m$ & $3 m$ & $m$ & $3 m$ & $m$ & $3 m$ & $m$ & $3 m$ & $m$ & $3 m$ & $m$ & $3 m$ \\
\hline Minimum & 0 & 0 & -100 & -100 & -100 & -88 & -100 & -84 & -100 & -96 & -35 & -24 \\
\hline Mean & 1 & 4 & 11 & 11 & 0 & 0 & 3 & 3 & -1 & -1 & 1 & 0 \\
\hline Maximum & 99 & 130 & 4246 & 2890 & 393 & 217 & 287 & 164 & 271 & 132 & 40 & 25 \\
\hline Min. date & many & many & many & many & many & 8/1931 & many & $8 / 1902$ & $7 / 1883$ & $8 / 1902$ & 12/1991 & $2 / 1929$ \\
\hline Max. date & $10 / 1953$ & $11 / 1953$ & $9 / 2000$ & $9 / 2000$ & $8 / 1888$ & 8/1899 & $8 / 1995$ & $5 / 1883$ & $9 / 2000$ & $9 / 2000$ & $3 / 2001$ & $3 / 2001$ \\
\hline
\end{tabular}

Table 3. Cross-correlation coefficient $(\mathrm{lag}=0)$ of yearly time series of floods $(F)$ and of indexes of floods (IF), precipitation (IP), wet days (ID), precipitation intensity (II), and temperature (IT).

\begin{tabular}{lllllll}
\hline & $F$ & IF & IP & ID & II & IT \\
\hline$F$ & 1 & & & & & \\
IF & 1 & 1 & & & & \\
IP & 0.44 & 0.44 & 1 & & & \\
ID & 0.22 & 0.22 & 0.66 & 1 & & \\
II & 0.19 & 0.19 & 0.52 & -0.09 & 1 & \\
IT & 0.10 & 0.01 & 0.00 & -0.39 & 0.34 & 1 \\
\hline
\end{tabular}

was considered, we could distinguish two periods, defined as fold trend: the earlier, from 1880 to 1974 , showed increasing floods, while the period from 1974 to 2007 showed a slight decrease in floods. This recent decreasing trend could have been due to the effect of less (or at least not increasing) hazardous climatic conditions noted and/or the result of the increasing awareness of floods risks. However, this second contribution should be verified using analyses finalised to verify 1) if flood vulnerability was either reduced or stabilised by the effect of mitigation works, and (2) if better land use practices have been recently implemented. The analysis of the yearly time series was repeated and the yearly moving averages of each parameter were calculated for 2, 3, 5, and $10 \mathrm{yr}$. The results obtained were quite similar, and the correlation coefficients decreased as the number of years increased. This was observed for each index with the exception of $T$, for which the coefficient increased.

The minimum number of floods per decade was observed in the last decade of the nineteenth century, which could have been related to low values of both rainfall and rainfall intensity (the 10-yr moving average showed the lowest values of IP and II in 1895). The peak flood number observed in the 1950s seemed justifiable considering the very high precipitation and number of wet days observed. It is possible to determine $\mathrm{CC}^{m}$ for the monthly time series of IF with the monthly time series of each index (Table 4). The peak was observed for $m=12$ months, except for ID. It should be noted that the correlation with temperature was very low, while $\mathrm{CC}^{m}$, for each couple of parameters, showed very low variability.
Table 4. Cross-correlation coefficient of monthly time series of monthly index of floods (IF) with indexes of precipitation (IP), wet days (ID), precipitation intensity (II), and temperature (IT) with variable $m$-month ( $m=1,2,3,6$, and 12$)$.

\begin{tabular}{rrrrr}
\hline$m$ & IP & ID & II & IT \\
\hline 1 & 0.26 & 0.13 & 0.21 & -0.01 \\
2 & 0.36 & 0.20 & 0.26 & 0.00 \\
3 & 0.36 & 0.18 & 0.24 & 0.02 \\
6 & 0.39 & 0.18 & 0.21 & 0.05 \\
12 & 0.40 & 0.20 & 0.19 & 0.07 \\
\hline
\end{tabular}

\section{Conclusions}

A method to characterise the statistical relationship between flood occurrences and climatic parameters has been defined and tested on an extensive Italian region. The method is based on a comparative analysis of historical data on floods and climatic indexes obtained by elaborating all available instrumental measurements.

The huge amount of data required to characterise the climatic trend of the region was synthesised in a series of indexes used in the comparative analysis of the trends of climatic parameters and flood occurrences. These indexes made it easier to study the considered phenomena, which showed significant spatial and temporal variability, and helped to define a methodological approach based on the typical tools of time series analysis. This approach eliminated any significant effects of gaps in the climatic series.

The analysis of the monthly time series highlighted the main role of precipitation, wet days, and, secondly, precipitation intensity on flood occurrence.

The climatic and flood analyses showed: (a) a decreasing trend of precipitation and wet days, (b) the almost constant value of precipitation intensity, (c) the increasing trend of temperature, and (d) a linear trend of floods significantly increasing. It was notable that the decreasing trend of rainfall was due to both the decrease in the number of wet days and the amount of rainfall that occurred in the higher rainfall frequency classes. 
The trends of the climatic variables cannot justify the increase in flood occurrence. On refining the analysis of the flood trend, two periods were distinguished (fold trend): the earlier, from 1880 to 1974, showed increasing floods, while the later, from 1974 to 2007, showed a slight decrease of floods.

Due to both the regional distribution of population and the river network characteristics, flood damage affected the terminal tracks of both fiumaras and rivers. Damaged elements are mainly cultivated fields, rural settlements, transportation networks, and seaside villages and towns.

When the relationship between climate and floods was analysed in terms of a straight linear trend of floods, the conclusion was that despite the trends of the climatic parameters were unfavourable to increases in flood occurrence, floods were not decreasing. Nevertheless, the interpretation based on the fold trend seems more realistic; the change in flood trend, observed roughly in the seventies, could be consistent with climatic changes discussed on a wider scale. According to Polemio and Casarano (2008), the climate trend in southern Italy seems due to a clear discontinuity in the time series which can be observed roughly starting from 1980. Additionally, Conversi et al. (2010) highlighted a regime shift during the 1980s, from atmospheric, hydrological and ecological points of view, that was linked to the Northern Hemisphere climate and affected the whole Mediterranean Sea.

At the same time, it can be hypothesised that the flood trend change was partially due to an increasing awareness of floods risks, even if quantitative data concerning the changes that happened in previous decades in the region would need to be gathered to prove this hypothesis. Moreover, in southern Italy there are numerous examples of short periods characterised by decreases in flood damage following implementation of protective efforts (Petrucci and Polemio, 2007; Polemio, 2010), although these periods ended more or less abruptly due to the improvident utilisation of flood-prone areas because of the progressive decline of community flood awareness in the absence of damaging floods.

More efforts will be necessary to take into account the effects of main atmospheric mechanisms by highlighting the effective contribution of rain events due to frontal systems and convective storms. At the same time, a deeper characterisation of the temperature effect on net rainfall and the role of antecedent conditions on floods should be investigated. Any possible effort will be pursued to reduce existing difficulties in moving towards an effective daily or hourly approach to the analysis of climatic time series, considering the intrinsic difficulty in improving the temporal accuracy of historical flood data. In addition, deeper investigations should be pursued to refine the analysis using regionalisation criteria.
Acknowledgements. The authors are grateful to the editor, A. Loukas, and the referees, George Karatzas, J. A. Ortega, and another anonymous referee for the constructive comments which greatly improved the quality of the work.

Edited by: A. Loukas

Reviewed by: P. Karatzas, J. A. Ortega, and another anonymous referee

\section{References}

Adhikari, P., Hong, Y., Douglas, K. R., Kirschbaum, D. B., Gourley, J., Adler, R., and Brakenridge, G. R.: A digitized global flood inventory (1998-2008): compilation and preliminary results, Nat. Hazards, 55, 405-422, 2010.

Agasse, E.: Flooding during the 17th to 20th centuries in Normandy (western France): methodology and use of historical data, in: Palaeofloods, Historical Floods and Climatic Variability: Applications in Flood Risk Assessment, edited by: Thorndycraft, V. R., Benito, G., Barriendos, M., and Llasat, M. C., Proceedings of the PHEFRA Workshop, Barcelona, 16-19th October, 2002, 99-105, 2003.

Antoine, J. M., Desailly, B., and Gazelle, F.: Les crues meurtrières, du Roussillon aux Cévennes, Annales de Géographie, 622, $597-$ 623, 2001.

ASICal (Aree Storicamente Inondate in Calabria): available at: http://www.camilab.unical.it/, last access: 8 October 2010.

Balasch, J. C., Ruiz-Bellet, J. L., Tuset, J., and Martín de Oliva, J.: Reconstruction of the 1874 Santa Tecla's rainstorm in Western Catalonia (NE Spain) from flood marks and historical accounts, Nat. Hazards Earth Syst. Sci., 10, 2317-2325, doi:10.5194/nhess-10-2317-2010, 2010.

Barredo, J. I.: Normalised flood losses in Europe: 1970-2006, Nat. Hazards Earth Syst. Sci., 9, 97-104, doi:10.5194/nhess-997-2009, 2009.

Barredo, J. I.: No upward trend in normalised windstorm losses in Europe: 1970-2008, Nat. Hazards Earth Syst. Sci., 10, 97-104, doi:10.5194/nhess-10-97-2010, 2010.

Barriendos, M. and Martin-Vide, J.: Secular climatic oscillations as indicated by Catastrophic floods in the Spanish Mediterranean Coastal area (14th-19th centuries), Climatic Change, 38, 473491, 1998.

Bartl, S., Schümberg, S., and Deutsch, M.: Revising time series of the Elbe river discharge for flood frequency determination at gauge Dresden, Nat. Hazards Earth Syst. Sci., 9, 1805-1814, doi:10.5194/nhess-9-1805-2009, 2009.

Benito, G., Herrero, A. D., and De Villalta M. F.: Magnitude and frequency of flooding in the Tagus basin (central Spain) over the last millennium, Climatic Change, 58, 171-192, 2003.

Benito, G., Lang, M., Barriendos, M., Llasat, M. C., Francés, F. Ouarda, T., Thorndycraft, V. R., Enzel, Y., Bardossy, A., Coeur, D., and Bobée, B.: Use of Systematic, Palaeoflood and Historical Data for the Improvement of Flood Risk Estimation, Review of Scientific Methods, Nat. Hazards., 31, 623-643, 2004.

Böhm, O. and Wetzel, K. F.: Flood history of the Danube tributaries Lech and Isar in the Alpine foreland of Germany, Hydrolog. Sci. J., 51, 784-798, 2006.

Box, G. E. P. and Jenkins, G. M.: Time Series Analysis: Forecasting and Control, Prentice Hall PTR, 592 pp., 1994. 
Brázdil, R. and Kundzewicz, Z. W.: Historical hydrology - Editorial Hydrological Sciences, Special issue: Historical Hydrology, Hydrolog. Sci. J., 51, 733-738, 2006.

Brissette, F. P., Leconte, R., Marche, C., and Rouselle, J.: Historical evolution of flooding damage on a USA/Quebec River Basin, J. Am. Water Res. A., 39, 1385-1396, 2003.

Brockwell, P. J. and Davis, R. A: Time series: Theory and methods, Springer-Verlag, 519 pp., 1987.

Brunetti, M., Buffoni, L., Mangianti, F., Maugeri, M., and Nanni, T.: Temperature, precipitation and extreme events during the last century in Italy, Glob. Planet. Change, 40, 141-149, 2004.

Brunetti, M., Maugeri, M., Monti, F., and Nanni, T.: Temperature and precipitation variability in Italy in the last two centuries from homogenised instrumental time series, Int. J. Climatol., 26, 345381, 2006

Brunetti, M., Caloiero, T., Coscarelli, R., Gullà, G., Nanni, T., and Simolo, C.: Extreme daily rainfall trend in Calabria, in: Le modificazioni climatiche e i rischi naturali, edited by: Polemio, M., CNR IRPI, Bari, Italy, 57-60, 2011 (in Italian).

Copien, C., Frank, C., and Becht, M.: Natural hazards in the Bavarian Alps: a historical approach to risk assessment, Nat. Hazards., 45, 173-181, 2008.

Craddock, J. M.: Methods for comparing annual rainfall records for climatic purpose, Weather, 34, 332-346, 1979.

Conversi, A., Fonda Umani, S., Peluso, T., Molinero, J. C., Santojanni, A., and Edwards, M.: The Mediterranean Sea Regime Shift at the End of the 1980s, and Intriguing Parallelisms with Other European Basins, PLoS ONE, 5, e10633, doi:10.1371/journal.pone.0010633, 2010.

Cunge, J. A., Holly, F. M., and Verwey, A.: Practical aspects of computational river hydraulics, Pitman Publishing Ltd., London, 420 pp., 1980.

EEA: Impacts of Europe's changing climate, An indicator-based assessment, European Environment Agency Report, 4, http://www. eea.europa.eu/publications/eea_report_2008_4/, 2008.

Elmer, F., Thieken, A. H., Pech, I., and Kreibich, H.: Influence of flood frequency on residential building losses, Nat. Hazards Earth Syst. Sci., 10, 2145-2159, doi:10.5194/nhess-10-21452010, 2010.

EMA (Emergency Management Australia): Disaster loss assessment guidelines, available at: www.ema.gov.au, 2002, last access: 10 November 2010.

Fairbridge, R. W.: The encyclopaedia of geomorphology, Reinhold, New York, 1968.

Glaser, R. and Stangl, H.: Historical floods in the Dutch Rhine Delta, Nat. Hazards Earth Syst. Sci., 3, 605-613, doi:10.5194/nhess-3-605-2003, 2003.

Glaser, R. and Stangl, H.: Climate and floods in central Europe since AD 1000: data, methods, results and consequences, Surv. Geophys., 25, 485-510, 2004.

Glaser, R., Riemann, D., Schönbein, J., Barriendos, M., Brázdil, R., Bertolin, C., Camuffo, D., Deutsch, M., Dobrovolný, P., van Engelen, A., Enzi, S., Halíková, M., Koenig, S. J., Kotyza, O., Limanówka, D., Macková, J., Sghedoni, M., Martin, B., and Himmelsbach, I.: The variability of European floods since AD 1500, Climatic Change, 101, 235-256, 2010.

Goovaerts, P.: Geostatistics for natural resources evaluation, Oxford University Press, USA, 483 pp., 1997.

Gupta, S., Javed, A., and Datt, D.: Economics of Flood Protection in India, Nat. Hazards, 28, 199-210, 2003.

Hannaford, J. and Marsh, T. J.: High-flow and flood trends in a network of undisturbed catchments in the UK, Int. J. Climatol., 28, 1325-1338, 2008.

Herget, J. and Meurs, H.: Reconstructing peak discharges for historic flood levels in the city of Cologne, Germany, Glob. Planet. Change, 70, 108-116, 2010.

Hirsch, R. M., Slack, J. R., and Smith, R. A.: Techniques of trend analysis for monthly water quality data, Water Resour. Res., 18, 107-121, 1982.

Hirschboeck, K. K., Ely, L., and Maddox, R. A., Hydroclimatology of meteorologic floods, in: Inland Flood Hazards: Human, Riparian and Aquatic Communities, edited by: Wohl, E., Cambridge University Press, 39-72, 2000.

Ibbeken, H. and Schleyer, R.: Source and sediment, a case study of provenance and mass balance at an active plate margin (Calabria), Springer Verlag, 286 pp., 1991.

IPCC: Climate Change 2001: Impacts, Adaptation and Vulnerability, in: Contribution of Working Group II to the third assessment report of the Intergovernmental Panel on Climate Change, edited by: McCarthy, J. J., Canziani, O. F., Leary, N. A., Dokken, D. J., and White, K. S., Cambridge University Press, 1000 pp., 2001.

ISTAT: Bilancio demografico nazionale: Calabria, available at: http://www.istat.it/salastampa/comunicati/non_calendario/ 20040726_01/calabria.pdf, 2003.

Jenkinson, A. F.: The frequency distribution of the annual maximum (or minimum) values of meteorological elements, Q. J. R Meteorol. Soc., 81, 158-171, 1955.

Jonkman, S. and Kelman, I.: An analysis of the causes and circumstances of flood disaster deaths, Disasters, 29, 75-97, 2005.

Kendall, M. G.: Rank Correlation Methods, Charles Griffin, London, 160 pp., 1975.

Lara, A., Saurí, D., Ribas, A., and Pavón, D.: Social perceptions of floods and flood management in a Mediterranean area (Costa Brava, Spain), Nat. Hazards Earth Syst. Sci., 10, 2081-2091, doi:10.5194/nhess-10-2081-2010, 2010.

Llasat, M. C.: Storms and floods, in: The Physical Geography of the Mediterranean basin, edited by: Woodward, J., Oxford University Press, 504-531, 2009.

Llasat, M. C., Barriendos, M., and Barrera, A.: Floods in Catalonia (NE Spain) since the 14th century, Climatological and meteorological aspects from historical documentary sources and old instrumental records, J. Hydrol., 313, 32-47, 2005.

Mann, H. B.: Non parametric tests against trend, Econometrica, 13, 245-259, 1945.

Merz, B., Kreibich, H., Schwarze, R., and Thieken, A.: Review article "Assessment of economic flood damage", Nat. Hazards Earth Syst. Sci., 10, 1697-1724, doi:10.5194/nhess-10-16972010, 2010.

Mudelsee, M., Börngen, M., Tetzlaff, G., and Grünewald, U.: Extreme floods in central Europe over the past 500 years: Role of cyclone pathway "Zugstrasse Vb", J. Geophys. Res., 109, 1-21, doi:10.1029/2004JD005034, 2004.

Naulet, R., Lang, M., Ouarda, T. B. M. J., Coeur, D., Bobe, B., Recking, A., and Moussay, D.: Flood frequency analysis on the Ardèche river using French documentary sources from the last two centuries, J. Hydrol., 313, 58-78, 2005.

Ogniben, L.: Schema geologico della Calabria in base ai dati odierni, Geologica Romana, 12, 243-585, 1973. 
Ortega, J. A. and Garzón, G.: A contribution to improved flood magnitude estimation in base of palaeoflood record and climatic implications - Guadiana River (Iberian Peninsula), Nat. Hazards Earth Syst. Sci., 9, 229-239, doi:10.5194/nhess-9-2292009, 2009.

Petrucci, O. and Pasqua, A. A.: The study of past damaging hydrogeological events for damage susceptibility zonation, Nat. Hazards Earth Syst. Sci., 8, 881-892, doi:10.5194/nhess-8-8812008, 2008.

Petrucci, O. and Polemio, M.: Flood risk mitigation and anthropogenic modifications of a coastal plain in southern Italy: combined effects over the past 150 years, Nat. Hazards Earth Syst. Sci., 7, 361-373, doi:10.5194/nhess-7-361-2007, 2007.

Petrucci, O. and Polemio, M.: The role of meteorological and climatic conditions in the occurrence of damaging hydro-geologic events in Southern Italy, Nat. Hazards Earth Syst. Sci., 9, 105118, doi:10.5194/nhess-9-105-2009, 2009.

Petrucci, O., Pasqua, A. A., and Gullà, G.: Landslide damage assessment using the Support Analysis Framework (SAF): the 2009 landsliding event in Calabria (Italy), Adv. Geosci., 26, 1317, doi:10.5194/adgeo-26-13-2010, 2010a.

Petrucci, O., Polemio, M., and Pasqua, A. A.: Flash floods risk variation of steep drainage basins in Calabria (Italy) and the role of rainfall and anthropogenic modifications since 1800, Global Change: Facing Risks and Threats to Water Resources (Proc. of the Sixth World FRIEND Conference, Fez, Morocco, October 2010), IAHS, Publ. 340, 2010, 103-110, 2010 b.

Petrucci, O., Polemio, M., and Pasqua, A.: Analysis of damaging hydro-geological events: the case of Calabria region (southern Italy), Environ. Manage., 43, 483-495, doi:10.1007/s00267-0089234-z, 2009.

Pielke, R. A. and Downton, M. W.: Precipitation and damaging floods: trends in the United States, 1932-97, Am. Meteorol. Soc., 13, 3625-3637, 2000.

Pielke Jr., R. A., Gratz, J., Landsea, C. W., Collins, D., Saunders, M. A., and Musulin, R.: Normalized hurricane damage in the United States: 1900-2005, Nat. Hazards Rev., 9, 29-42, 2008.

Polemio, M.: Extreme rainfall events and floods in a karstic environment (Southern Italy), Z. Geomorphologie, 54, 195-219, 2010.

Polemio, M. and Casarano, D.: Climate change, drought and groundwater availability in southern Italy, in: Climate Change and Groundwater, Geological Society, edited by: Dragoni, W., London, Special Publications, 288, 39-51, 2008.
Polemio, M. and Petrucci, O.: Occurrence of landslide events and the role of climate in the twentieth century in Calabria, southern Italy, Quart. J. Eng. Geol. Hydro., 43, 1-14, 2010.

Rohr, C.: Measuring the frequency and intensity of floods of the Traun River (Upper Austria), 1441-1574, Hydrol. Sci. J., 5, 834847, 2006.

Ruin, I., Creutin, J. D., Anquetin, S., and Lutoff, C.: Human exposure to flash-floods - relation between flood parameters and human vulnerability during a storm of September 2002 in Southern France, J. Hydrol., 361, 199-213, doi:10.1016/j.jhydrol.2008.07.044, 2008.

Saint-Laurent, D., Mesfioui M., and Evin, G.: Hydroclimatic variability and relation with flood events (Southern Québec, Canada), Water Resour., 36, 43-56, 2009.

Schmocker-Fackel, P. and Naef, F.: Changes in flood frequencies in Switzerland since 1500, Hydrol. Earth Syst. Sci., 14, 1581-1594, doi:10.5194/hess-14-1581-2010, 2010.

Seidel, J., Imbery, F., Dostal, P., Sudhaus, D., and Bürger, K.: Potential of historical meteorological and hydrological data for the reconstruction of historical flood events - the example of the 1882 flood in southwest Germany, Nat. Hazards Earth Syst. Sci., 9, 175-183, doi:10.5194/nhess-9-175-2009, 2009.

Sen, P. K.: Estimates of the regression coefficient based on Kendall's tau, J. Amer. Stat. Ass., 63, 1379-1389, 1968.

Thiel, H.: A rank-invariant method of linear and polynomial regression analysis, Part 3, Proceedings of Koninalijke Nederlandse Akademie van Weinenschatpen A., 53, 1397-1412, 1950.

Tortorici, L.: Lineamenti geologico-strutturali dell'Arco CalabroPeloritano, Rendiconti della Società Italiana di Mineralogia e Petrologia, 38, 972-940, 1982.

Vinet, F.: Geographical analysis of damage due to flash floods in southern France: the cases of 12-13 November 1999 and 8-9 September 2002, Appl. Geogr., 28, 323-336, 2008.

Viparelli, M.: La sistemazione delle aste terminali delle fiumare calabre, Università di Napoli, Istituti Idraulici, Pubbl. N. 276, 95 pp., 1972.

Wahlin, K. and Grimvall, A.: Roadmap for assessing regional trends in groundwater quality, Environ. Monitor. As., 165, 217-231, 2010.

White, G. F., Kates, R. W., and Burton, I.: Knowing better and losing even more: the use of knowledge in hazards management, Environ. Hazards, 3, 81-92, 2001. 